Article

\title{
Impact of Future Land Use Change on Large Carnivores Connectivity in the Polish Carpathians
}

\author{
Dominik Kaim ${ }^{1, *(1)}$, Elżbieta Ziółkowska ${ }^{2}$, Marcin Szwagrzyk ${ }^{1}$, Bronwyn Price ${ }^{3}$ and \\ Jacek Kozak ${ }^{1}$ (D)
}

1 Faculty of Geography and Geology, Institute of Geography and Spatial Management, Jagiellonian University, Gronostajowa 7, 30-387 Kraków, Poland; marcin.szwagrzyk@doctoral.uj.edu.pl (M.S.); jacek.kozak@uj.edu.pl (J.K.)

2 Faculty of Biology, Institute of Environmental Sciences, Jagiellonian University, Gronostajowa 7, 30-387 Kraków, Poland; e.ziolkowska@uj.edu.pl

3 Swiss Federal Research Institute WSL, Land Change Science, Zürcherstrasse 111, 8903 Birmensdorf, Switzerland; bronwyn.price@wsl.ch

* Correspondence: dominik.kaim@uj.edu.pl; Tel.: +48-12-664-5323

Received: 28 November 2018; Accepted: 28 December 2018; Published: 4 January 2019

\begin{abstract}
The Polish Carpathians, like many mountain areas in Europe, are currently facing dynamic land use changes that will shape their future landscapes. As there are many different possible scenarios of potential change, we compared three different land use scenarios up until the year 2060 and assessed their impact on the potential habitat connectivity of two large carnivores-wolf (Canis lupus) and lynx (Lynx lynx). We first analysed the main directions of change within and outside the pan-European wildlife corridor located in the western part of the Polish Carpathians. Then we calculated and compared least-cost paths among randomly selected points for each land use scenario separately. Our results showed that the main direction of change-forest cover increase-may positively influence habitat connectivity for both wolf and lynx. However, due to the future spread of settlements, this positive impact might be locally limited. Therefore, to realise the potential conservation opportunities resulting from on-going land use changes, adequate orientation of spatial planning towards habitat connectivity is crucial.
\end{abstract}

Keywords: land use scenarios; large mammals; habitat connectivity; land abandonment; settlement development; the Carpathians

\section{Introduction}

Landscapes across the globe are increasingly subject to alteration by humans, with the associated land use and land cover changes having considerable consequences for biodiversity [1-3]. In human-dominated landscapes, survival of faunal species can depend on habitat connectivity [4], which, for example, facilitates gene flow among subpopulations and enhances resilience to climate change and other disturbances [5]. Assessment of changes in habitat composition, configuration and quality, as well as habitat connectivity are particularly important for large mammals, given their large spatial requirements and disproportionate importance for ecosystem functioning [6]. Large mammals are also important umbrella species, i.e., their protection automatically implies the protection of other species [7]. As the existence of large mammals in human-dominated landscapes depends on wildlife corridors, they are commonly used as a conservation strategy to counter the effects of habitat loss and fragmentation for those species [8].

Land use change is one of the main drivers of biodiversity decline worldwide [9]. Analyses of land use change dynamics conducted at the global scale indicate the continuation of current trends of habitat 
conversion and degradation into the future [2,3]. Titeux et al. [10] argue that the role of land use changes for future biodiversity assessments is still underestimated. Settlement development and the associated expansion of transportation networks are among the most disturbing changes affecting spatial and functional continuity of habitats and wildlife corridors [11,12]. Although the development of built-up areas is projected to occur mainly around cities [13], habitat fragmentation is also increasing due to settlement development in rural areas [14]. Studies have also shown that the expansion of built-up areas is observed in regions facing population decline due to increasing demand for per capita living space $[15,16]$. This is particularly important in the proximity of conservation hotspots often located far from urban centres [1,17]. The monitoring of settlement development in rural areas is therefore crucial for any biodiversity and conservation-oriented landscape management measures [18]. At the same time, many rural areas, for instance in Europe, are also experiencing increases in forested areas $[19,20]$. This is often the result of abandonment of the least profitable agricultural land [21,22], especially in mountain areas $[19,23,24]$. The interplay of settlement expansion and forest cover increase occurring concurrently in many areas shows the complexity of interactions between various socio-economic processes and of their impact on future biodiversity [14]. Those processes may, however, vary spatially due to regional differences in land use dynamics.

The Carpathian Mountains are an important biodiversity hotspot in Europe, where dynamic socio-economic changes have heightened the interplay between settlement expansion and forest cover increase [25]. Following the political transformation processes of the 1980s and 1990s, two land use processes were dominant within the region: (1) agricultural land abandonment leading to forest cover increase, and (2) spread of built-up areas together with infrastructure and transport development $[20,26,27]$. Forest cover increase can be considered a beneficial process for many species for which forests provide shelter or food resources, expanding habitat for forest-dwelling large mammals, such as brown bears or wolves [28]. Settlement and transport infrastructure development, by contrast, are considered key barriers to the movement of large mammals [29-31]. There is, therefore, a need to quantify how these ongoing land use changes may transform future Carpathian landscapes, influencing habitats and their connectedness.

The aim of this study is to assess the potential impact of land use changes up to the year 2060 in the Carpathians on habitat connectivity for two species of large mammals, wolf (Canis lupus) and lynx (Lynx lynx). The case study region is located in the western part of the Polish Carpathians, which faces increasing agricultural land abandonment as well as the expansion of settlements. We focus on analysing changes taking place within and around the pan-European wildlife corridor crossing the study area, addressing the question of how the habitat connectivity of key large carnivores will be affected by likely trajectories of land use change under three different scenarios of socio-economic development in the Polish Carpathians.

\section{Materials and Methods}

\subsection{Study Area}

The study area, located in the western part of the Polish Carpathians, consists of three neighbouring powiats (NUTS 4 administrative units in Poland): Bielski, Cieszyński and Żywiecki. The $1785 \mathrm{~km}^{2}$ area (Figure 1) is dominated by forest cover and is intersected by the main pan-European, Carpathian ecological corridor, crossing Poland, Slovakia and Czechia [32]. The study area is subject to several drivers of land use change, including suburbanisation and development of tourist infrastructure. This stimulates an unplanned spread of built-up areas and infrastructure as well as development of transportation routes, often affecting remote areas in proximity to forests. The intensity of these processes, however, vary across the study area. While in the Bielski powiat, suburbanisation processes are the dominant land use threat to future habitat connectivity, in the Cieszyński powiat, dynamic tourist infrastructure development, including demand for second homes, is the main issue [33]. In the Żywiecki powiat, suburbanisation processes are less visible, but development 
of tourist infrastructure may affect the vast and best preserved forest areas in the region. The powiats of the study area differ also with respect to demographic trends. Official projections indicate that the number of inhabitants will increase in the Bielski powiat until 2050. On the contrary, the population is projected to decrease in the Żywiecki powiat in the same period, and in the Cieszyński powiat the maximum population level is projected to be reached in the 2020s [34].

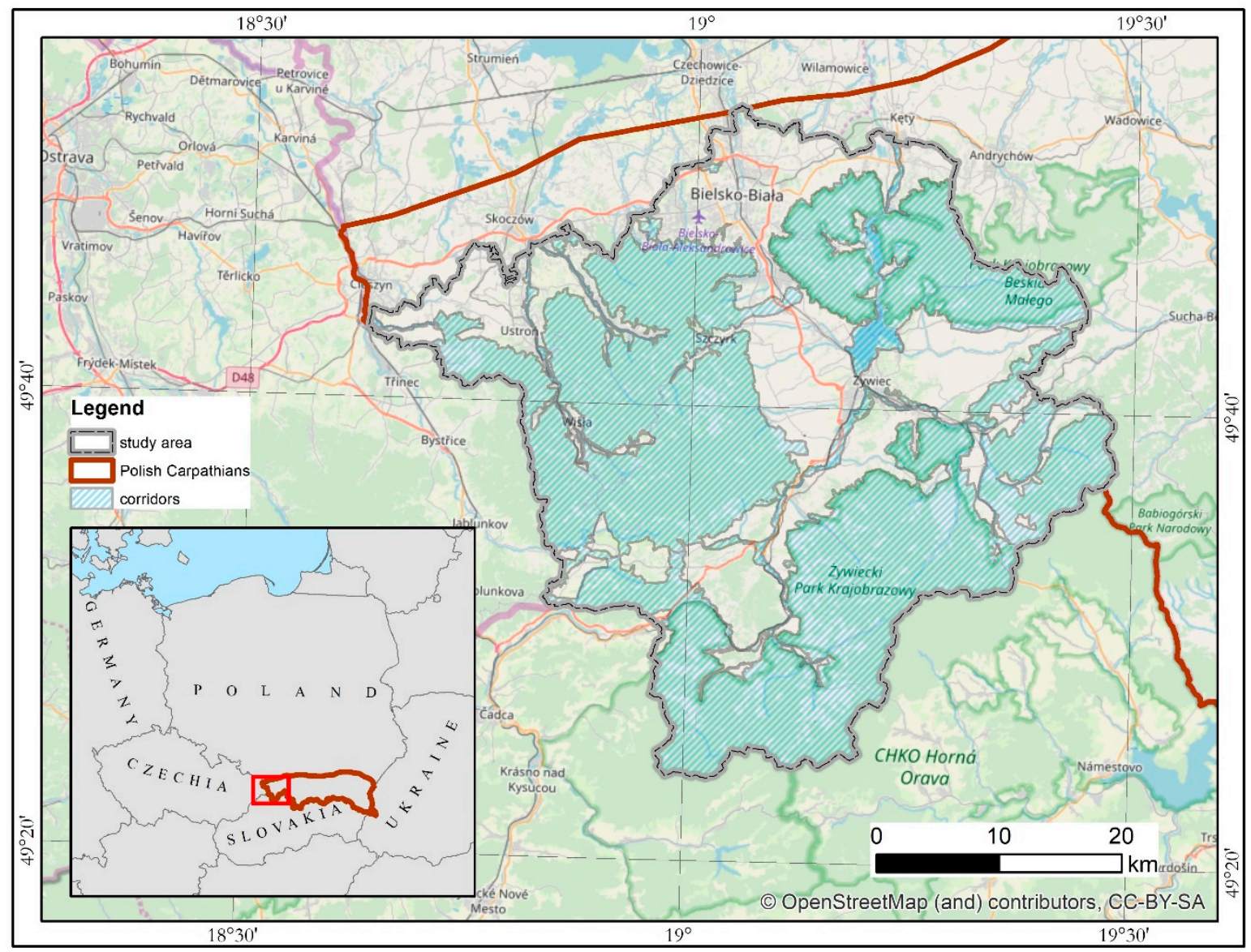

Figure 1. Study area with core habitat areas and corridors designed for mammals by the Centre for Natural Heritage of Upper Silesia [35].

\subsection{Approach}

To investigate the potential impacts of future land use change on habitat connectivity, a land use change scenario approach was used in association with least-cost path modelling. In the modelling, we used maps of the future (year 2060) land use developed for the Polish Carpathians in a previous study based on three land use change scenarios ('trend', 'liberalisation' and 'self-sufficiency') [36]. We focused on the evaluation of potential habitat connectivity for large mammals, using wolf (Canis lupus) and lynx (Lynx lynx) as model species, where potential habitat connectivity combines information on landscape structure with limited information on species' dispersal abilities, as defined by Calabrese and Fagan [37]. For each of three land use change scenarios, resistance to movement maps were created for wolf (Canis lupus) and lynx (Lynx lynx) separately, with resistance values based on the literature. We further performed a connectivity analysis using a least-cost path analysis. The scenario outputs were compared with each other and with the 'current' status to examine potential changes in connectivity for wolf and lynx in response to future land use changes. 


\subsection{Input Data}

Maps of the future land use for the Polish Carpathians for 2060 were developed in a previous study by Price et al. [36]. In that study, future land use was modelled within the DynaCLUE modelling framework [38] with five land use classes (forest, overgrown, grassland, arable land, settlements) for 194 communes located in the Polish Carpathians, using three scenarios: trend, liberalisation and self-sufficiency. The scenarios were developed using a story and simulation approach [39], with outputs varying along a globalisation to regionalisation axis and a market orientation versus regulatory control axis. The trend scenario was based on the extrapolation of the land use dynamics observed in the region between 1970 and 2013, when the main land use change directions were agricultural land abandonment resulting in forest cover increase, as well as development of settlements [40]. The liberalisation scenario assumed market-oriented future socio-economic development, low support for agricultural and conservation subsidies and little regulatory control on urbanisation, resulting in higher agricultural land abandonment and an increase of settlement areas. The self-sufficiency scenario was defined by regional growth with emphasis on agricultural self-sufficiency, landscape conservation measures and agricultural subsidies triggering lower rates of land abandonment and, as a consequence, more concentrated settlement development. The scenarios were modelled from the 2013 national land use vector data stored in the database of topographic objects for Poland (Baza Danych Obiektów Topograficznych; BDOT10k), re-categorised into five classes (forest, overgrown, grassland, arable land, settlements). Future land use maps with $100 \mathrm{~m}$ spatial resolution were then computed using DynaCLUE land use allocation based on a set of explanatory variables: slope, distance to roads, mean summer temperature (including future projections), population density (including future projections) and number of hotels per capita (as an indicator of tourism demand). Future projections of mean summer temperatures were derived from climate change scenario data obtained from EURO-COR-DEX (www.euro-cordex.net) for the representative concentration pathways (RCPs) 4.5 (self-sufficiency scenario) and 8.5 (trend and liberalisation scenario) [41]. The future population projection was determined from Central Statistical Office of Poland (GUS) population scenarios [34]. Future demands for the settlements were based on different per capita urban demands, depending on the scenario [36]. The scenario modelling is further detailed in Price et al. [36].

Wildlife corridors and core habitat areas for wolf and lynx for the Silesia Province were received from the Centre for Natural Heritage of Upper Silesia. They were delineated using a combined approach linking habitat suitability analyses and least-cost modelling [35]. As the study area can be characterised as the region of either permanent or sporadic occurrence of wolf and lynx [42,43], we combined the core habitat areas and wildlife corridors into one class and refer to them as the corridors throughout the paper.

\subsection{Land Use Change and Connectivity Assessment}

Modelled land use changes in the period 2013-2060 were analysed within and around the wildlife corridor and core habitats intersecting the study area for each scenario-dependent future land use map separately. Both absolute and relative changes with reference to $2013(100 \%)$ were reported and mapped. Additionally, to analyse the impact of land use change on landscape pattern, we compared the number of forest and settlements patches as indicators of forest fragmentation and settlement aggregation, both being important factors affecting habitat connectivity maintenance and improvement. The number of forest and settlement patches were compared among land use change scenarios and in reference to the current state, within and outside of the corridor.

To assess impacts of potential changes in land use on the potential habitat connectivity of large carnivores (wolf and lynx), we first defined species-specific resistance values for each land use type, following the approach of Huck et al. [30]. For each species, those resistance values represented the costs of movement through different land use types, creating resistance to movement maps according to current and future land use (separately for each scenario). The resistance values were based on the Huck et al. analysis [30], where cost of movement was defined for wolf and lynx under the 
environmental conditions of Poland, with low values indicating little resistance to movement for the study species. As land use change scenarios did not distinguish between different forest types, resistance values originally proposed by Huck et al. [30] for different forest types were averaged to one value (Table 1). Similarly, the value assigned to grasslands was averaged from the values of meadows and pastures. Next, for each scenario and species separately, we calculated least-cost paths between pairs of ten randomly selected points located within the corridor, with minimum in-between distance of $3 \mathrm{~km}$. Ten point pairs was the maximum number that could be contained within the relatively small study area without repeat coverage of the same movement paths. Least-cost analysis were performed with the Linkage Mapper Toolkit [44], which provides the shortest connections (Euclidean distances) among core areas, as well as least-cost paths. Core areas were defined as the point pairs. The differences in connectivity among scenarios and in comparison to current state were analysed with the connectivity index of path tortuosity defined as the ratio of length of the least-cost path and the Euclidean distance between each of the connected points. The higher the path tortuosity, the lower the potential connectivity between given locations.

Table 1. Resistance to movement values for wolf (Canis lupus) and lynx (Lynx lynx), where lower values represent lower resistance to movement.

\begin{tabular}{ccc}
\hline Land Use Class & Wolf Cost & Lynx Cost \\
\hline forest & 8 & 16 \\
overgrown & 32 & 43 \\
grassland & 46 & 62 \\
arable land & 100 & 100 \\
settlements & 68 & 72 \\
\hline
\end{tabular}

\section{Results}

\subsection{Land Use Changes}

A substantial future forest cover increase outside the corridor was noted, from the current $13.2 \%$ up to $18.1 \%, 25.4 \%$ and $28.2 \%$, according to the future land use maps based on the self-sufficiency, the trend and the liberalisation scenarios, respectively (Table 2, Figure 2). At the same time, all scenarios predicted a decrease in arable land and grassland and a slight increase in settlements, which was highest for the land use map based on the liberalisation scenario. Overgrown areas were projected to increase in the liberalisation scenario and to decrease in the two other scenarios (Table 2, Figure 2).

Table 2. Future land use changes out of the corridor (\%).

\begin{tabular}{ccccc}
\hline Land Use & $\mathbf{2 0 1 3}$ & Trend & Liberalisation & Self-Sufficiency \\
\hline forest & 13.2 & 25.4 & 28.2 & 18.1 \\
overgrown & 3.1 & 3.0 & 4.9 & 2.2 \\
grassland & 36.8 & 26.9 & 24.1 & 34.0 \\
arable land & 18.6 & 15.7 & 13.0 & 16.7 \\
settlements & 28.3 & 29.0 & 29.7 & 29.0 \\
\hline
\end{tabular}

Although an increase in forest cover was also projected within the corridor, the changes were not substantial (up to $8.8 \%$ ), however, the initial forest coverage within the corridor was already high $(81.1 \%)$ in 2013 . Similarly, overgrown areas increased slightly (from $0.7 \%$ to $2.0-2.6 \%$ ), while settlement area was stable ( $2.3 \%$ to $2.4-2.5 \%$; Table 3, Figure 2). At the same time, both grassland and arable land were projected to decrease considerably within the corridor (Table 3, Figure 2). 
Table 3. Future land use changes within the corridor (\%).

\begin{tabular}{ccccc}
\hline Land Use & $\mathbf{2 0 1 3}$ & Trend & Liberalisation & Self-Sufficiency \\
\hline forest & 81.1 & 89.3 & 89.9 & 84.7 \\
overgrown & 0.7 & 2.0 & 2.6 & 2.1 \\
grassland & 13.3 & 5.0 & 4.1 & 9.5 \\
arable land & 2.6 & 1.2 & 0.9 & 1.4 \\
settlements & 2.3 & 2.5 & 2.5 & 2.4 \\
\hline
\end{tabular}

As for the relative changes, the largest forest cover increase was projected by the liberalisation scenario $(214 \%)$, and the smallest by the self-sufficiency scenario $(36 \%)$ (Figure 3a). The future land use map based on the liberalisation scenario showed a substantial increase in overgrown areas $(157 \%)$ and settlements (105\%) (Figure 3a). While grassland and arable land were projected to decrease outside the corridor for all three scenarios, the maps based on the trend and self-sufficiency scenarios demonstrated a decrease in overgrown areas (Figure 3a).

In 2013, forest cover was the dominant class within the corridor, and the projections showed that it will increase its dominance in the future (Figure 3b). However, the most visible relative change projected within the corridor was the increase in overgrown areas (up to 363\% in the liberalisation scenario). At the same time, grassland and arable land were projected to decrease substantially, while settlements were projected to increase slightly (Figure $3 b$ ).
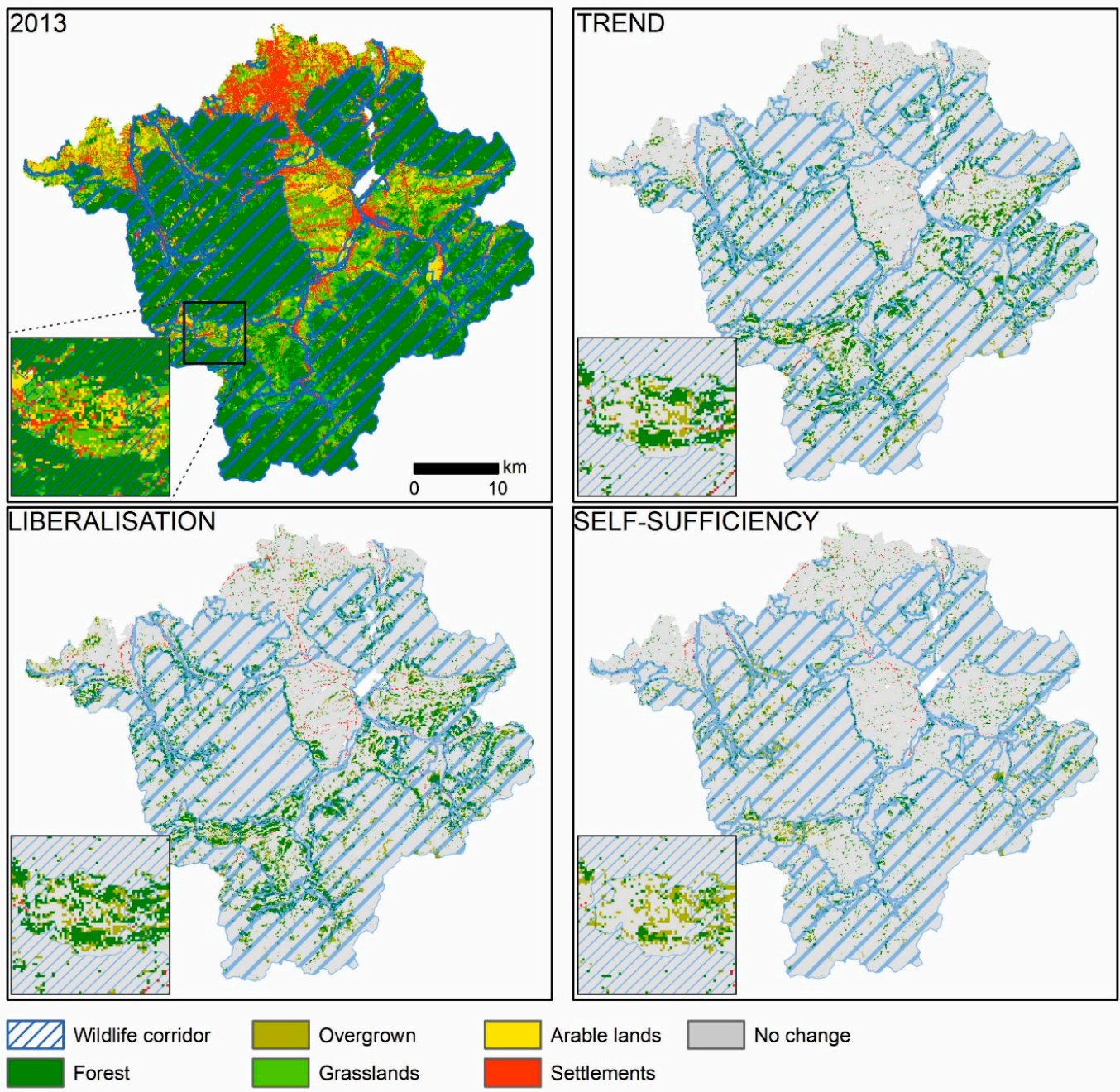

Arable lands

Settlements

Figure 2. Current land use and future land use changes for the three scenarios. The zoom-in shows two bottleneck areas within the corridor, which restrict the movement of animals. 


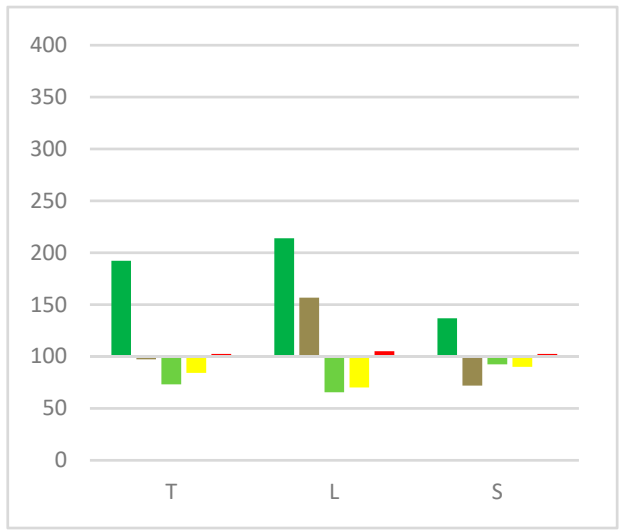

(a)

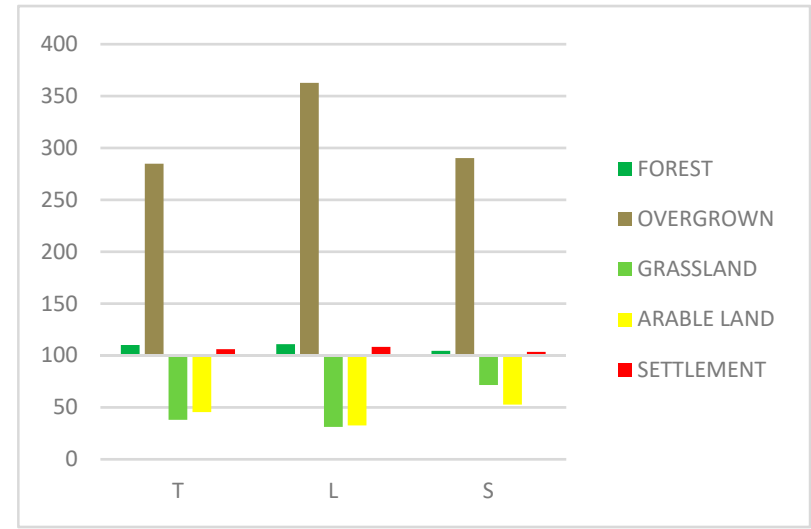

(b)

Figure 3. Relative land use changes $(2013=100 \%)$ outside $(\mathbf{a})$ and within $(\mathbf{b})$ the wildlife corridor between 2013 and 2060 for future land use maps based on the three scenarios ( $\mathrm{T}$, trend; L, liberalisation; S, self-sufficiency).

The number of forest patches within the corridor was found to be increasing only in the self-sufficiency scenario, while future land use maps based on the trend and liberalisation scenarios showed a decrease in the forest patch number (Figure 4). Outside the corridor, a decrease was found only for the trend scenario, while in the liberalisation and self-sufficiency scenarios the number of forest patches increased substantially (Figure 4). Regardless of the scenario, the number of settlement patches increased slightly within the corridor and decreased outside the corridor (Figure 4).

within the corridor

$\begin{array}{ll} & 2000 \\ & 1500 \\ \text { forest } & 1000\end{array}$
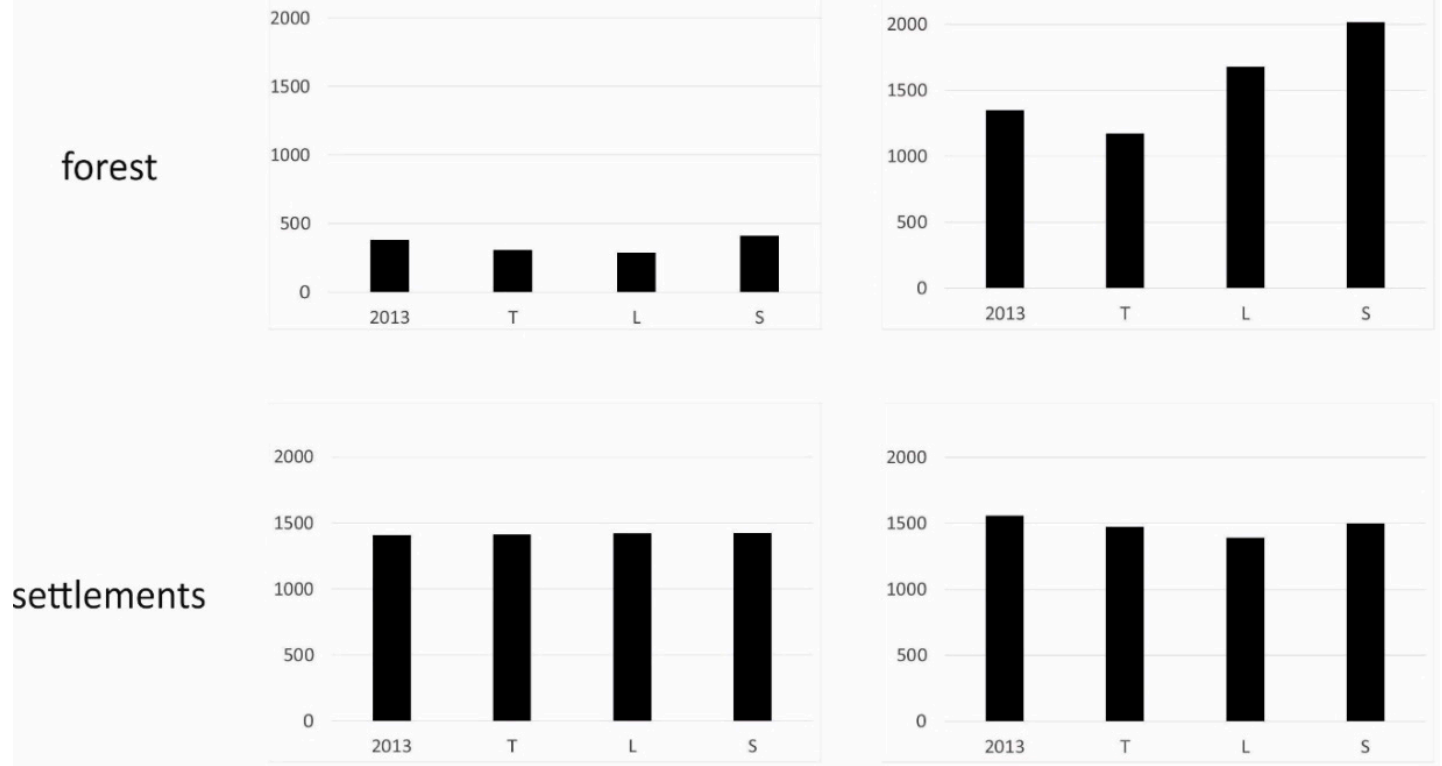

Figure 4. Number of patches of forest and settlements within and outside the corridor for the current state of land use and the future land use maps based on the three scenarios ( $T$, trend; $L$, liberalisation; $\mathrm{S}$, self-sufficiency).

\subsection{Connectivity Changes in Response to Future Land Use}

A comparison of path tortuosities $(n=20)$ showed improved future habitat connectivity in the study area for both large carnivores (wolf and lynx), regardless of the scenario (Figures 5 and 6). 
The highest connectivity improvement was noted for the liberalisation scenario, while the smallest improvement was found for the future land use based on the self-sufficiency scenario (Figure 6).

2013
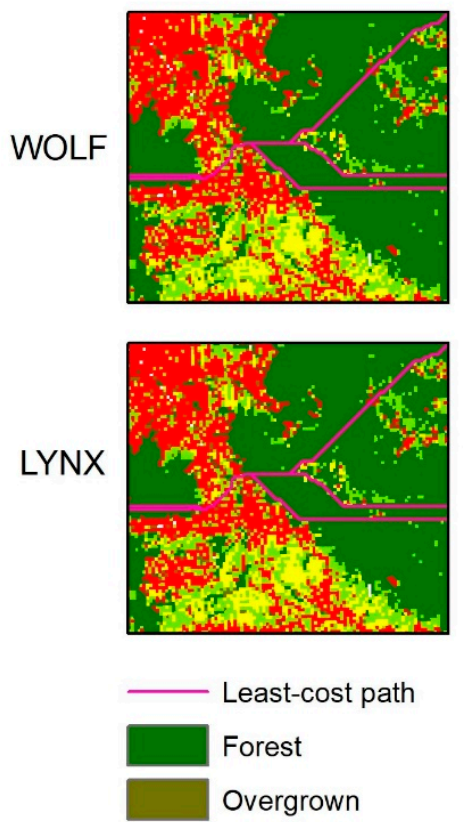

$\mathrm{T}$
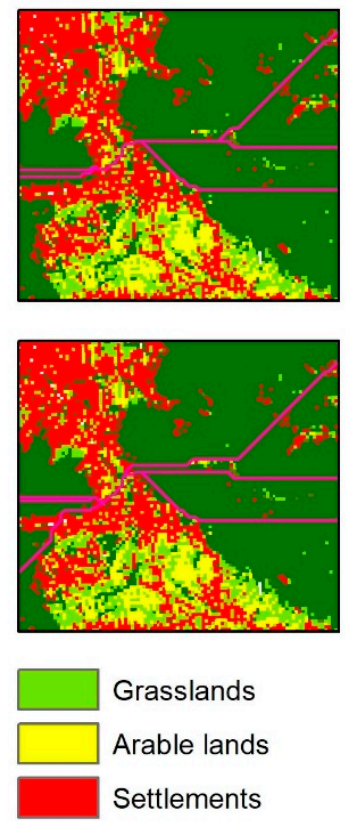

Grasslands

Arable lands

Settlements
L
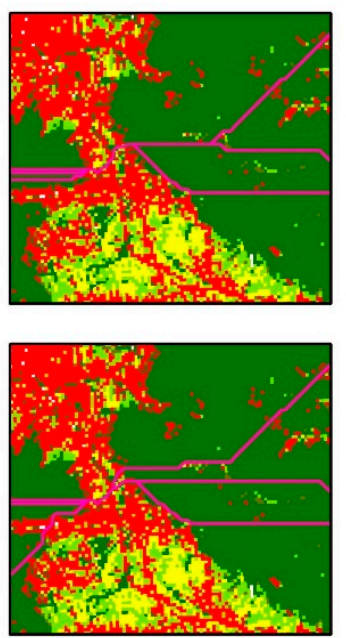

0

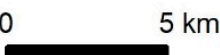

S
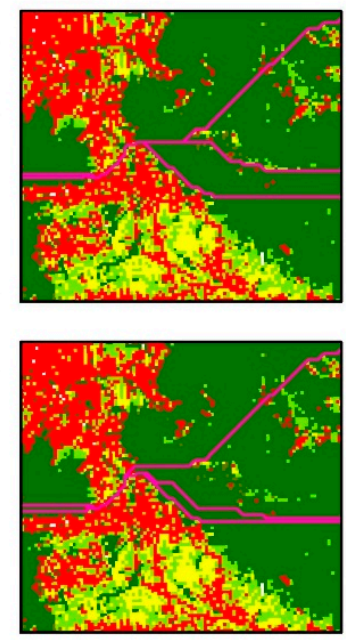

Figure 5. Least-cost paths for wolf and lynx for the current and future land use, for three scenarios-an example for the northern part of the study area (T, trend; L, liberalisation; $\mathrm{S}$, self-sufficiency).

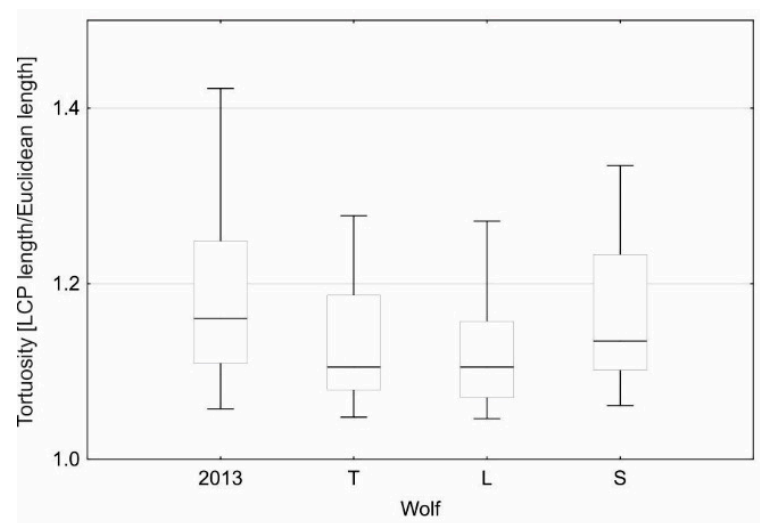

(a)

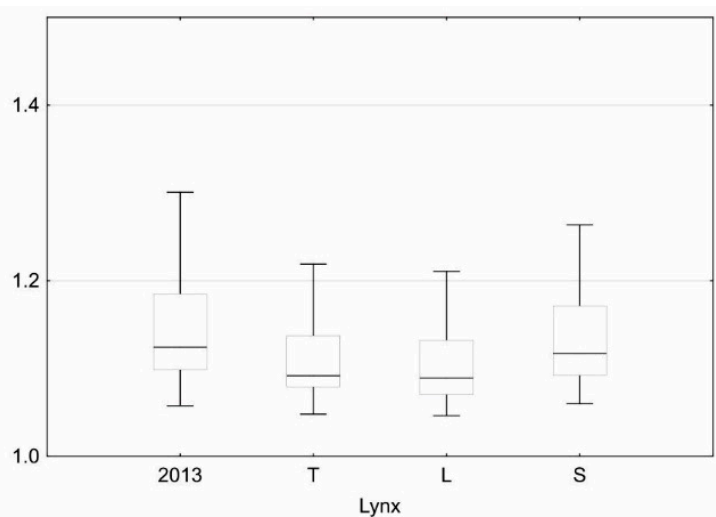

(b)

Figure 6. Path tortuosity index (LCP - least-cost path length/Euclidean length) for current and future land use maps based on the three scenarios ( $T$, trend; L, liberalisation; S, self-sufficiency), for wolf (a) and $\operatorname{lynx}(\mathbf{b})$.

\section{Discussion}

Using a least-cost path approach in association with scenarios of potential future land use change, this study demonstrates that potential habitat connectivity of large mammals, specifically wolf and lynx, can be expected to improve within the Polish Carpathians across a range of scenarios for the year 2060. The results emphasise that the ongoing trend of farm abandonment and forest increase which faces many areas of lynx and wolf habitat, particularly in the Carpathians [25], may improve potential habitat connectivity. However, this may be tempered by settlement increases unless there is careful spatial planning. 
According to the future land use scenarios, the western part of the Polish Carpathians will face substantial changes between now and 2060. We found, however, that areas located within and outside of the corridor will experience different future land use trajectories, and hence will have different future land use patterns. In the areas located outside the corridor, the main processes projected by land use scenarios were forest cover increase and settlement development, while an increase in overgrown areas was projected only by the liberalisation scenario (Table 2). Within the wildlife corridor, by contrast, land abandonment leading to the expansion of overgrown areas was predicted in all scenarios. Forest cover and settlement development increases were also projected within the corridor, but their relative increases were not as considerable. Forest cover was, however, already very high within the corridor in 2013, and settlements constituted only a minor land use type (Table 3).

Along with the projected forest cover increase in the corridor, its fragmentation (measured by the number of forest patches) decreased. This may be explained by the fact that in areas already dominated by forest, one of the major patterns of forest expansion is through the closure of core openings within forest perforations (such as the disappearance of former pastures or other previously agriculturally managed clearings), leading to landscape homogenisation [20]. As the areas located within wildlife corridor are, in general, characterised by higher elevations and steep slopes, this confirms the role of biophysical factors in the abandonment of agricultural land in the Carpathians [27]. In contrast, a substantial forest increase outside of the corridor was projected along with increased forest fragmentation in two out of three of the land use scenarios (Figure 4). This might be the result of the fact that agricultural land abandonment in the Polish Carpathians affects mainly small privately owned land parcels on which cultivation has become unprofitable [27]. As a consequence, this leads to overgrowth and, over a longer perspective, the appearance of many new but small forest patches, thus increasing overall forest fragmentation, especially at the lower elevations [45]. The consideration of habitat configuration, and specifically fragmentation, is important for the conservation of large mammals, since studies have shown that large well-connected patches are essential to achieving species conservation goals [46].

Both within and outside of the corridor, agricultural land was projected to decrease and forest cover was projected to increase (Tables 2 and 3), which potentially could be beneficial not only for wolves and lynx [30] but also for other forest-dwelling mammals [31,47,48]. Proportion of agricultural lands has also been found to be negatively correlated with wolf occurrence in other studies [49]. The conducted least-cost analysis showed that projected land use changes will reduce the resistance to movement in the study area for both wolf and lynx. Predicted forest cover increase can therefore counteract the negative influence of settlement development, as reflected in the decrease of path tortuosity (Figure 5). However, it is worth highlighting that the positive connectivity changes foreseen in the future scenarios were the lowest for the self-sufficiency scenario and the highest for the liberalisation scenario (Figure 5). The self-sufficiency scenario assumed sustainable regional development and increased concern for ecological issues, with a specific focus on the preservation of agricultural subsidies and local agriculture [36]. Therefore, for this scenario the active prevention of agricultural land abandonment resulted in less afforestation as compared to the other two scenarios. This somehow counterintuitive outcome of our analysis means that despite the storyline of high ecological awareness [36], threats to biodiversity related to land use changes are very complex. While the projected increase in forest cover would support habitats and habitat connectivity for forest-dwelling species, the agricultural land abandonment and decrease in grassland areas could be an important threat to many open farmland or grassland-associated species [50,51]. Even in national parks, there are considerable challenges facing the management and maintenance of grasslands for conservation and protection [52], with often greater difficulties outside the protected areas. The knowledge of potential future land use change provides guidance for the design of effective conservation policies, which then could be implemented by local or regional environmental protection institutions or agencies.

Although the projected increase in settlements over the study area was found to be marginal, it may be of high importance for habitat connectivity. Settlement development and the associated increase in transportation infrastructure is an important physical barrier [31] and a threat for animal 
movement $[12,31,53]$. Currently the study area is crossed by a railway line and a motorway, with limited possibilities for safe crossing by wildlife. Furthermore, the existing underpass is not used by large mammals [54], indicating that they have to cross the transportation network in other locations. This shows that proper planning of road and railroad crossings is needed in the area to avoid the isolation of habitats and limit collision risk for moving animals. Improperly planned highways may act as home range barriers for large mammals [46].

Aside from being a physical barrier, the development of settlement and transportation networks, even in small amounts, can have other considerable impacts on habitat quality and species movement. Due to an increased presence of people in the area, edge effects, noise [45] and light pollution [46], larger areas could be affected beyond the development itself. According to future land use scenarios, the number of settlement patches will decrease outside the wildlife corridor, potentially indicating a more compact settlement development pattern. However, at the same time, the number of settlement patches was projected to increase slightly within the corridor, which may have a negative impact on habitat connectivity. More scattered settlements usually require longer roads, and even small roads may limit movement possibilities in relatively favourable conditions, as was found in the case of the European bison (Bison bonasus) in the Carpathians [31]. Any road creation may also trigger large decreases in roadless areas, which are crucial for conservation measures improvement, especially in Europe [12]. Additionally, more settlement combined with forest cover increase may develop more wildland-urban interfaces (WUIs) - the areas where settlement and wildland vegetation meet or intermingle [14]. It has been shown that animal behaviour is more risky in WUIs [55,56] and human-animal conflicts are more likely in WUIs, negatively affecting wildlife conservation efforts [57]. In the past, a significant WUI increase was observed in the study area [58], and our results showed that this increase may also continue in the future.

Although our case study area constitutes only a small part of the whole Carpathian ecoregion, the observed land use changes and resulting pressures on biodiversity are similar to those projected for the Polish Carpathians in general [36], and are therefore important for the functional continuity of the whole pan-European Carpathian corridor and neighbouring areas. For instance, Carpathian wolves were observed at a distance of $300 \mathrm{~km}$ from their origin location, demonstrating the importance of the study area for further dispersion [59]. Future spatial planning policies, on local, regional, national and pan-European levels should therefore take into account that the area of the Western Carpathians is important not only for the Polish or Slovak large carnivore populations but also populations at the continental scale [42].

\section{Conclusions}

Our results showed that the future land use changes in the Polish Carpathians are likely to improve the habitat connectivity of large carnivores under a range of different scenarios with different socio-economic growth assumptions. This confirms the thesis that farmland abandonment can be considered as an opportunity for rewilding ecosystems [60]. As the general directions of potential future land use changes for the whole Polish Carpathians are in line with the results presented here [36], we argue that proper land use planning and conservation policy are needed in order to transform this opportunity into conservation success.

Author Contributions: Conceptualization: D.K., E.Z.; methodology: D.K., E.Z., M.S., J.K., B.P.; formal analysis: D.K.; writing_original draft preparation: D.K.; writing-review and editing: D.K., E.Z., M.S., J.K., B.P.; visualization: D.K., E.Z., M.S.

Funding: Future land use maps were developed within the FORECOM project (Forest-cover changes in mountainous regions-drivers, trajectories and implications, PSRP 008/2010), supported by a grant from Switzerland through the Swiss contribution to the enlarged European Union.

Acknowledgments: We are grateful to three anonymous reviewers who provided revisions to our paper. 
Conflicts of Interest: The authors declare no conflict of interest. The funders had no role in the design of the study; in the collection, analyses, or interpretation of data; in the writing of the manuscript, or in the decision to publish the results.

\section{References}

1. Hamilton, C.M.; Martinuzzi, S.; Plantinga, A.J.; Radeloff, V.C.; Lewis, D.J.; Thogmartin, W.E.; Heglund, P.J.; Pidgeon, A.M. Current and future land use around a nationwide protected area network. PLoS ONE 2013, 8, e55737. [CrossRef] [PubMed]

2. Newbold, T.; Hudson, L.N.; Hill, S.L.L.; Contu, S.; Lysenko, I.; Senior, R.A.; Börger, L.; Bennett, D.J.; Choimes, A.; Collen, B.; et al. Global effects of land use on local terrestrial biodiversity. Nature 2015, 520, 45-50. [CrossRef]

3. Visconti, P.; Bakkenes, M.; Baisero, D.; Brooks, T.; Butchart, S.H.M.; Joppa, L.; Alkemade, R.; Di Marco, M.; Santini, L.; Hoffmann, M.; et al. Projecting Global Biodiversity Indicators under Future Development Scenarios. Conserv. Lett. 2016, 9, 5-13. [CrossRef]

4. Fischer, J.; Lindenmayer, D.B. Landscape modification and habitat fragmentation: A synthesis. Glob. Ecol. Biogeogr. 2007, 16, 265-280. [CrossRef]

5. Bellard, C.; Bertelsmeier, C.; Leadley, P.; Thuiller, W.; Courchamp, F. Impacts of climate change on the future of biodiversity. Ecol. Lett. 2012, 15, 365-377. [CrossRef] [PubMed]

6. $\quad$ Estes, J.A.; Terborgh, J.; Brashares, J.S.; Power, M.E.; Berger, J.; Bond, W.J.; Carpenter, S.R.; Essington, T.E.; Holt, R.D.; Jackson, J.B.C.; et al. Trophic downgrading of planet Earth. Science 2011, 333, 301-306. [CrossRef] [PubMed]

7. Di Minin, E.; Slotow, R.; Hunter, L.T.B.; Montesino Pouzols, F.; Toivonen, T.; Verburg, P.H.; Leader-Williams, N.; Petracca, L.; Moilanen, A. Global priorities for national carnivore conservation under land use change. Sci. Rep. 2016, 6, 23814. [CrossRef] [PubMed]

8. Chetkiewicz, C.-L.B.; St. Clair, C.C.; Boyce, M.S. Corridors for Conservation: Integrating Pattern and Process. Annu. Rev. Ecol. Evol. Syst. 2006, 37, 317-342. [CrossRef]

9. Sala, O.E. Global Biodiversity Scenarios for the Year 2100. Science 2000, 287, 1770-1774. [CrossRef]

10. Titeux, N.; Henle, K.; Mihoub, J.-B.; Regos, A.; Geijzendorffer, I.R.; Cramer, W.; Verburg, P.H.; Brotons, L. Biodiversity scenarios neglect future land use changes. Glob. Chang. Biol. 2016, 22, 2505-2515. [CrossRef]

11. Selva, N.; Switalski, A.; Kreft, S.; Ibisch, P.L. Why keep areas road-free? The importance of roadless areas. In Handbook of Road Ecology; Van der Ree, R., Grilo, C., Smith, D., Eds.; Wiley-Blackwell: Oxford, UK, 2015; pp. 16-26. ISBN 978-1-118-56818-7.

12. Ibisch, P.L.; Hoffmann, M.T.; Kreft, S.; Pe'er, G.; Kati, V.; Biber-Freudenberger, L.; DellaSala, D.A.; Vale, M.M.; Hobson, P.R.; Selva, N. A global map of roadless areas and their conservation status. Science 2016, 354, 1423-1427. [CrossRef] [PubMed]

13. Seto, K.C.; Güneralp, B.; Hutyra, L.R. Global forecasts of urban expansion to 2030 and direct impacts on biodiversity and carbon pools. Proc. Natl. Acad. Sci. USA 2012, 109, 16083-16088. [CrossRef] [PubMed]

14. Radeloff, V.C.; Hammer, R.B.; Stewart, S.I.; Fried, J.S.; Holcomb, S.S.; McKeefry, J.F. The Wildland-Urban Interface in the United States. Ecol. Appl. 2005, 15, 799-805. [CrossRef]

15. Haase, D.; Kabisch, N.; Haase, A. Endless urban growth? On the mismatch of population, household and urban land area growth and its effects on the urban debate. PLoS ONE 2013, 8, e66531. [CrossRef] [PubMed]

16. Hennig, E.I.; Schwick, C.; Soukup, T.; Orlitová, E.; Kienast, F.; Jaeger, J.A.G. Multi-scale analysis of urban sprawl in Europe: Towards a European de-sprawling strategy. Land Use Policy 2015, 49, 483-498. [CrossRef]

17. Mcdonald, R.I.; Kareiva, P.; Forman, R.T.T. The implications of current and future urbanization for global protected areas and biodiversity conservation. Biol. Conserv. 2008, 141, 1695-1703. [CrossRef]

18. Carter, S.K.; Pohlman, J.D.; Bergeson, T.L.; Hamilton, C.M.; Pidgeon, A.M.; Radeloff, V.C. Improving the utility of existing conservation plans using projected housing development. Landsc. Urban Plan. 2014, 126, 10-20. [CrossRef]

19. Price, B.; Kienast, F.; Seidl, I.; Ginzler, C.; Verburg, P.H.; Bolliger, J. Future landscapes of Switzerland: Risk areas for urbanisation and land abandonment. Appl. Geogr. 2015, 57, 32-41. [CrossRef]

20. Kaim, D. Land cover changes in the Polish Carpathians based on repeat photography. Carpathian J. Earth Environ. Sci. 2017, 12, 485-498. 
21. Lasanta, T.; Arnáez, J.; Pascual, N.; Ruiz-Flaño, P.; Errea, M.P.; Lana-Renault, N. Space-time process and drivers of land abandonment in Europe. CATENA 2017, 149, 810-823. [CrossRef]

22. Ustaoglu, E.; Collier, M.J. Farmland Abandonment in Europe: An Overview of Drivers, Consequences and Assessment of the Sustainability Implications. Environ. Rev. 2018, 26, 396-416. [CrossRef]

23. Stürck, J.; Levers, C.; van der Zanden, E.H.; Schulp, C.J.E.; Verkerk, P.J.; Kuemmerle, T.; Helming, J.; Lotze-Campen, H.; Tabeau, A.; Popp, A.; et al. Simulating and delineating future land change trajectories across Europe. Reg. Environ. Chang. 2015. [CrossRef]

24. Kolecka, N.; Kozak, J.; Kaim, D.; Dobosz, M.; Ginzler, C.; Psomas, A. Mapping Secondary Forest Succession on Abandoned Agricultural Land with LiDAR Point Clouds and Terrestrial Photography. Remote Sens. 2015, 7, 8300-8322. [CrossRef]

25. Munteanu, C.; Kuemmerle, T.; Boltiziar, M.; Butsic, V.; Gimmi, U.; Lúboš, H.; Kaim, D.; Király, G.; Konkoly-Gyuró, É.; Kozak, J.; et al. Forest and agricultural land change in the Carpathian region-A meta-analysis of long-term patterns and drivers of change. Land Use Policy 2014, 38, 685-697. [CrossRef]

26. Hostert, P.; Kozak, J.; Kaim, D.; Kuemmerle, T.; Mueller, D.; Ostapowicz, K. Land use and land cover change in the Carpathians after 1989. In Europe's Ecological Backbone: Recognizing the True Value of Our Mountains, EEA Report 6/2010; European Environment Agency: Copenhagen, Denmark, 2010; pp. 120-122.

27. Kolecka, N.; Kozak, J.; Kaim, D.; Dobosz, M.; Ostafin, K.; Ostapowicz, K.; Wężyk, P.; Price, B. Understanding farmland abandonment in the Polish Carpathians. Appl. Geogr. 2017, 88. [CrossRef]

28. UNEP (United Nations Environment Programme). Carpathians Environment Outlook; UNEP: Geneva, Switzerland, 2007.

29. Jędrzejewski, W.; Niedzialkowska, M.; Mysłajek, R.W.; Nowak, S.; Jędrzejewska, B. Habitat selection by wolves Canis lupus in the uplands and mountains of southern Poland. Acta Theriol. (Warsz.) 2005, 50, 417-428. [CrossRef]

30. Huck, M.; Jędrzejewski, W.; Borowik, T.; Miłosz-Cielma, M.; Schmidt, K.; Jędrzejewska, B.; Nowak, S.; Mysłajek, R.W. Habitat suitability, corridors and dispersal barriers for large carnivores in Poland. Acta Theriol. (Warsz.) 2010, 55, 177-192. [CrossRef]

31. Ziółkowska, E.; Perzanowski, K.; Bleyhl, B.; Ostapowicz, K.; Kuemmerle, T. Understanding unexpected reintroduction outcomes: Why aren't European bison colonizing suitable habitat in the Carpathians? Biol. Conserv. 2016, 195, 106-117. [CrossRef]

32. Jongman, R.H.G.; Bouwma, I.M.; Griffioen, A.; Jones-Walters, L.; Van Doorn, A.M. The Pan European Ecological Network: PEEN. Landsc. Ecol. 2011, 26, 311-326. [CrossRef]

33. Mika, M. Spatial Patterns of Second Homes Development in the Polish Carpathians. In The Carpathians: Integrating Nature and Society towards Sustainability SE-35; Kozak, J., Ostapowicz, K., Bytnerowicz, A., Wyżga, B., Eds.; Environmental Science and Engineering; Springer: Berlin/Heidelberg, Germany, 2013; pp. 497-512. ISBN 978-3-642-12724-3.

34. GUS. Prognoza Ludności na Lata 2014-2050; GUS: Warszawa, Poland, 2014.

35. Parusel, J.B.; Skowrońska, K.; Wower, A. Korytarze Ekologiczne w Województwie Ślaskim—Koncepcja do Planu Zagospodarowania Przestrzennego Województwa. Etap I.; Centrum Dziedzictwa Przyrody Górnego Ślaska: Katowice, Poland, 2007.

36. Price, B.; Kaim, D.; Szwagrzyk, M.; Ostapowicz, K.; Kolecka, N.; Schmatz, D.R.; Wypych, A.; Kozak, J. Legacies, socio-economic and biophysical processes and drivers: The case of future forest cover expansion in the Polish Carpathians and Swiss Alps. Reg. Environ. Chang. 2017, 17, 2279-2291. [CrossRef]

37. Calabrese, J.M.; Fagan, W.F. A comparison-shopper's guide to connectivity metrics. Front. Ecol. Environ. 2004, 2, 529-536. [CrossRef]

38. Verburg, P.H.; Overmars, K.P. Combining top-down and bottom-up dynamics in land use modeling: Exploring the future of abandoned farmlands in Europe with the Dyna-CLUE model. Landsc. Ecol. 2009, 24, 1167-1181. [CrossRef]

39. Alcamo, J. Chapter Six The SAS Approach: Combining Qualitative and Quantitative Knowledge in Environmental Scenarios. Dev. Integr. Environ. Assess. 2008, 2, 123-150. [CrossRef]

40. Kozak, J.; Ostapowicz, K.; Szablowska-Midor, A.; Widacki, W. Land abandonment in the Western Beskidy Mts and its environmental background. Ekológia (Bratisl.) 2004, 23, 116-126.

41. Wypych, A.; Ustrnul, Z.; Schmatz, D.R. Long-term variability of air temperature and precipitation conditions in the Polish Carpathians. J. Mt. Sci. 2018, 15, 237-253. [CrossRef] 
42. Chapron, G.; Kaczensky, P.; Linnell, J.D.C.; von Arx, M.; Huber, D.; Andrén, H.; López-Bao, J.V.; Adamec, M.; Álvares, F.; Anders, O.; et al. Recovery of large carnivores in Europe's modern human-dominated landscapes. Science 2014, 346, 1517-1519. [CrossRef]

43. Kutal, M.; Váňa, M.; Suchomel, J.; Chapron, G.; López-Bao, J.V. Trans-Boundary Edge Effects in the Western Carpathians: The Influence of Hunting on Large Carnivore Occupancy. PLoS ONE 2016, 11, e0168292. [CrossRef]

44. McRae, B.H.; Kavanagh, D.M. Linkage Mapper Connectivity Analysis Software 2011. Available online: http:/ / www.circuitscape.org/linkagemapper (accessed on 3 January 2019).

45. Kozak, J.; Ziółkowska, E.; Vogt, P.; Dobosz, M.; Kaim, D.; Kolecka, N.; Ostafin, K. Forest-cover increase does not trigger forest-fragmentation decrease: Case Study from the Polish Carpathians. Sustainbility 2018, 10, 1472. [CrossRef]

46. Schadt, S.; Knauer, F.; Kaczensky, P.; Revilla, E.; Wiegand, T.; Trepl, L. Rule-based assessment of suitable habitat and patch connectivity for the Eurasian lynx in Germany. Ecol. Appl. 2002, 12, 1469-1483. [CrossRef]

47. Ziółkowska, E.; Ostapowicz, K.; Kuemmerle, T.; Perzanowski, K.; Radeloff, V.C.; Kozak, J. Potential habitat connectivity of European bison (Bison bonasus) in the Carpathians. Biol. Conserv. 2012, 146, 188-196. [CrossRef]

48. Bleyhl, B.; Baumann, M.; Griffiths, P.; Heidelberg, A.; Manvelyan, K.; Radeloff, V.C.; Zazanashvili, N.; Kuemmerle, T. Assessing landscape connectivity for large mammals in the Caucasus using Landsat 8 seasonal image composites. Remote Sens. Environ. 2017, 193, 193-203. [CrossRef]

49. Votsi, N.-E.P.; Zomeni, M.S.; Pantis, J.D. Evaluating the Effectiveness of Natura 2000 Network for Wolf Conservation: A Case-Study in Greece. Environ. Manag. 2016, 57, 257-270. [CrossRef]

50. Halada, L'.; David, S.; Hreško, J.; Klimantová, A.; Bača, A.; Rusňák, T.; Bural', M.; Vadel, L'. Changes in grassland management and plant diversity in a marginal region of the Carpathian Mts. in 1999-2015. Sci. Total Environ. 2017, 609, 896-905. [CrossRef] [PubMed]

51. Tokarczyk, N. Forest encroachment on temperate mountain meadows-Scale, drivers, and current research directions. Geogr. Pol. 2017, 90, 463-480. [CrossRef]

52. Tokarczyk, N. Challenges for the conservation of semi-natural grasslands in mountainous national parks: Case studies from the Polish Carpathians. Carpathian J. Earth Environ. Sci. 2018, 13, 187-198.

53. Wynn-Grant, R.; Ginsberg, J.R.; Lackey, C.W.; Sterling, E.J.; Beckmann, J.P. Risky business: Modeling mortality risk near the urban-wildland interface for a large carnivore. Glob. Ecol. Conserv. 2018, 16, e00443. [CrossRef]

54. Myslajek, R.W.; Nowak, S.; Kurek, K.; Tolkacz, K.; Gewartowska, O. Utilisation of a wide underpass by mammals on an expressway in the Western Carpathians, S Poland. Folia Zool. 2016, 65, 225-232. [CrossRef]

55. Boutin, S. Hunger makes apex predators do risky things. J. Anim. Ecol. 2018, 87, 530-532. [CrossRef]

56. Blecha, K.A.; Boone, R.B.; Alldredge, M.W. Hunger mediates apex predator's risk avoidance response in wildland-urban interface. J. Anim. Ecol. 2018, 87, 609-622. [CrossRef]

57. Evans, M.J.; Rittenhouse, T.A.G.; Hawley, J.E.; Rego, P.W. Black bear recolonization patterns in a human-dominated landscape vary based on housing: New insights from spatially explicit density models. Landsc. Urban Plan. 2017, 162, 13-24. [CrossRef]

58. Kaim, D.; Radeloff, V.C.; Szwagrzyk, M.; Dobosz, M.; Ostafin, K. Long-term changes of the wildland-urban interface in the Polish Carpathians. ISPRS Int. J. Geo-Inf. 2018, 7, 137. [CrossRef]

59. Hulva, P.; Černá Bolfíková, B.; Woznicová, V.; Jindřichová, M.; Benešová, M.; Mysłajek, R.W.; Nowak, S.; Szewczyk, M.; Niedźwiecka, N.; Figura, M.; et al. Wolves at the crossroad: Fission-fusion range biogeography in the Western Carpathians and Central Europe. Divers. Distrib. 2018, 24, 179-192. [CrossRef]

60. Navarro, L.M.; Pereira, H.M. Rewilding Abandoned Landscapes in Europe. In Rewilding European Landscapes; Pereira, H.M., Navarro, L.M., Eds.; Springer International Publishing: Cham, Switzerland, 2015; pp. 3-23. ISBN 978-3-319-12039-3. 